\title{
Effect of Hydraulic Retention Time on the Levels of Biochemical Oxygen Demand and Total Suspended Solid with Simple Integrated Treatment as an Alternative to Meet the Household Needs for Clean Water
}

\author{
Zulfikar Zulfikar*, Nasrullah Nasrullah, Kartini Kartini, Wiwit Aditama \\ Department of Environmental Health, Health Polytechnic of the Ministry of Health, Aceh Besar, Indonesia
}

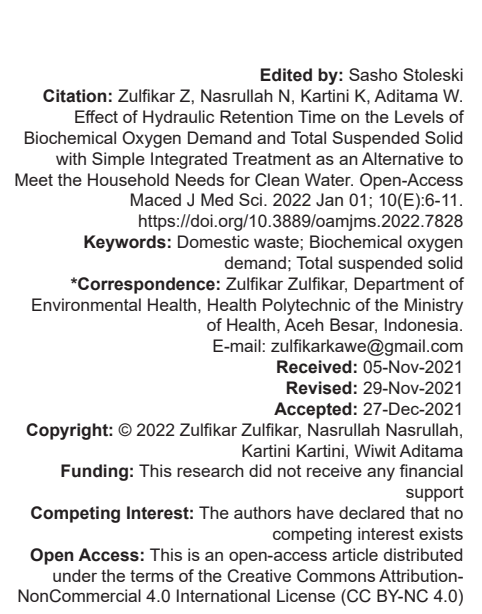

Abstract

BACKGROUND: Domestic wastewater can cause health problems and pollute groundwater sources. Such pollution not only has a negative impact on health and the environment but also on the cost in providing clean water.

AIM: The outcome of domestic wastewater treatment through a proper technique is expected to meet the clean water quality standard for sanitation purposes.

MATERIALS AND METHODS: The experiment was conducted to determine the effect of Hydraulic Retention Time (HRT) on the levels of Biochemical Oxygen Demand (BOD) and Total Suspended Solid (TSS) of domestic wastewater. The experiment was carried out with six variations of HRT, namely $1 \mathrm{~h}, 2 \mathrm{~h}, 4 \mathrm{~h}, 6 \mathrm{~h}$, and $8 \mathrm{~h}$ with four repetitions. The media running process was carried out for 14 days until the reactor condition was in steady state.

RESULTS: The results showed that the removal values for COD, Oil and Fat, Ammonia, and Total Coliform parameters were $68.03 \%, 46.51 \%, 69.64 \%$, and $68.99 \%$, respectively. Based on the variation of HRT of $1 \mathrm{~h}, 2 \mathrm{~h}, 4 \mathrm{~h}$, $6 \mathrm{~h}$, and $8 \mathrm{~h}$ on the BOD parameter, the removal values obtained were $11.7 \%, 21.3 \%, 34.7 \%, 49.0 \%$, and $64.1 \%$, respectively. Furthermore, for the TSS parameter, the values obtained were $17.3 \%, 25.4 \%, 30.6 \%, 42.3 \%$, and $50.4 \%$, respectively.

CONCLUSION: HRT was proven to have a significant effect on the levels of BOD and TSS of domestic wastewater with a $p<0.05$ at the $95 \%$ confidence level.

\section{Introduction}

Wastewater is water that has been used by humans from various activities which utilize clean water, for example, household, offices, shops, public facilities, industry, and other places [1], [2]. Domestic wastewater containing organic matter can decompose or be degraded by microorganisms. When such water is discharged into water bodies, it will increase the population of microorganisms, so as to increase Biochemical Oxygen Demand (BOD) levels while soap and detergents may cause an increase in water $\mathrm{pH}$ [3]. Domestic wastewater can adversely affect various things, because it can act as a carrier of disease, can cause damage to building materials and plants, and can damage the stability of life in water such as fish and other pets.

Domestic wastewater may also pollute water sources from shallow groundwater and surface water such as rivers. This pollution not only has a negative impact on health and the environment but also increases the cost in providing clean water. In general, the nature of domestic wastewater is divided into three characteristics, namely physical, chemical and biological characteristics. Physical characteristics relate to solids, oils, and fats; chemical characteristics relate to $\mathrm{pH}, \mathrm{BOD}, \mathrm{COD}$, and Ammonia; while biological characteristics relate to the number of coliforms [4].

The main purpose of wastewater treatment is to decompose the content of pollutants in the water, especially organic compounds, suspended solids, pathogenic microbes, and organic compounds that cannot be decomposed by microorganisms found in nature. The wastewater treatment can be divided into 4 (four) stages, namely primary treatment, secondary treatment, tertiary treatment, and sludge treatment [5] which includes physical, chemical, and biological treatment processes. The physical treatment process includes the use of screens, sedimentation, and grease traps. Meanwhile, the chemical treatment process can be implemented in the form of neutralization, oxidation, reduction, and ion exchange processes [6].

The biological treatment process is a wastewater treatment process performed by utilizing 
the growth activity of microorganisms in contact with wastewater, the contact time of microorganisms with wastewater. A good hydraulic retention time (HRT) for the aerobic process is more than $2 \mathrm{~h}$ [7] so that the microorganisms can use the existing polluting organic matter as food under certain environmental conditions and degrade or stabilize it into a simpler form. Microorganisms grow on the supporting media by forming a film layer to attach themselves to the sticky growth medium [3].

The outcome of domestic wastewater treatment is expected to meet clean water quality standard for use as daily necessities for washing, bathing, and latrines or at least being able to meet the standard wastewater originating from domestic liquid waste. In various places in Indonesia such as in the city of Banda Aceh, domestic wastewater has not been processed using waste treatment technology. In addition to the high cost and difficult implementation, the majority of people still think and have a view that direct disposal of household waste into the environment will not have a serious impact [8].

Currently, the city of Banda Aceh already has one Sludge Treatment Installation (IPLT) at Gampong Java. However, there is no centralized sewage treatment system along with the dirty water piping network (known as an off-site system) (Banda Aceh City Sanitation Team, 2009). Therefore, domestic waste will end up in Krueng Aceh or Krueng Daroy in the city of Banda Aceh [9]. In such conditions, an on-site treatment system for household waste is required. Based on the background of the problem, the authors are interested in conducting a study entitled "Effect of HRT on the Levels of Biological Chemical Demand and Total Suspended Solid (TSS) with Simple Integrated Treatment as an Alternative To Meet the Household Needs for Clean Water."

\section{Materials and Methods}

Household wastewater quality was measured before and after treatment regarding the parameters based on the Regulation of the Minister of Environment and Forestry of the Republic of Indonesia Number: 68 of 2016. Further, treatment was carried out to determine the effect of HRT on the levels of BOD and TSS of Domestic Wastewater (Grey Water) with 6-time variations and four repetitions.

\section{Early stage}

It was the stage for the preparation of the main equipment used in this study, namely a reactor assembled with seven filtering containers with a volume of 60 liters. The first and second containers were used as shelters, equalization tanks, screening, and grease trappers, the third container was used as a mechanical filter by using fisherman's nets, then the fourth and fifth containers were used as biological treatment by using biological media such as bioball and kaldness $\mathrm{K} 3$, then in the sixth and seventh containers were used for the chemical process by using filtration media of activated charcoal, zeolite sand, and shells to raise the $\mathrm{pH}$ of the water.

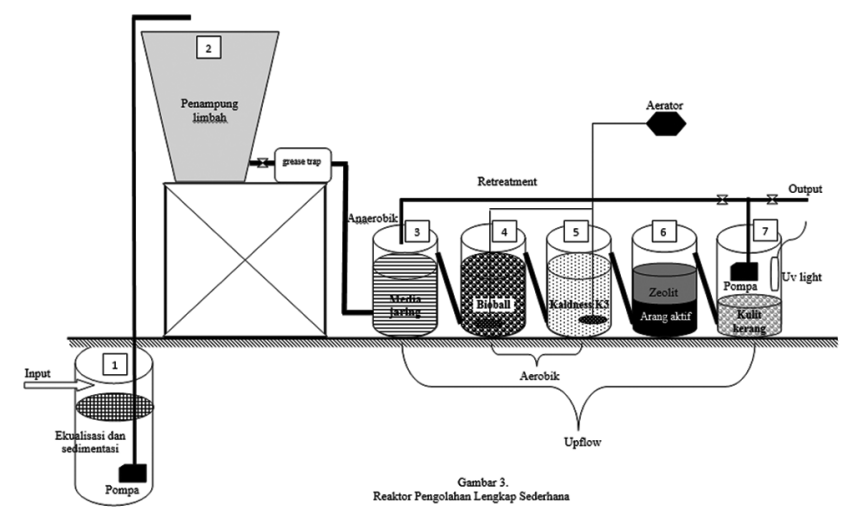

\section{Microbial seeding stage on filter media}

The next stage was microbial seeding on biological filter media, namely in the third and fourth containers as an aerobic treatment process. Bacterial seeding was carried out while running the reactor by adding $10 \%$ effective microorganisms to domestic wastewater along with aeration using an aerator. The running process was carried out for 14 days with constant circulation until the growth of microorganisms in the biological filter container became stable [10].

\section{Experiment implementation stage}

At the experimental stage, domestic wastewater was flowed into the first container as the first equalization process, sedimentation, and solids separation. Then, the wastewater was flowed into the second container for storage and second equalization as well as the grease trap process to remove oil and grease. The process was continued for mechanical filtration in the third container and the wastewater was then flowed into the fourth and fifth reactor containers for the aerobic process, then to the sixth container for the chemical treatment process, and further to the last container for the disinfection process. Flow circulation was maintained for sampling in each treatment of HRT, namely $1 \mathrm{~h}$, $2 \mathrm{~h}, 4 \mathrm{~h}, 6 \mathrm{~h}$, and $8 \mathrm{~h}$ and without treatment as a control group HRT. The experiment was repeated four times and then the levels of BOD and TSS were examined. 


\section{Results}

\section{Quality of domestic wastewater}

Waste quality parameters measured before and after treatment other than the levels of BOD and TSS based on the Regulation of the Minister of Environment and Forestry of the Republic of Indonesia No. P.68/Menlhk/Setjen/2016 were as follows:

Based on the Table 1, the examination before treatment for the $\mathrm{pH}$ parameter obtained a result of 5.8 which increased to 6.9 after treatment. For the COD, Oil and fat, Ammonia, and Total Coliform parameters, there were decreases after treatment by $68.03 \%, 46.51 \%$, $69.64 \%$ and $68.99 \%$, respectively.

Table 1: Results of measurement of domestic waste quality before and after treatment based on the Regulation of the Minister of Environment and Forestry of the Republic of Indonesia No. P.68/MenLHK/Setjen/2016

\begin{tabular}{lllll}
\hline S. No. & Parameter & Before & After & Unit \\
\hline 1. & $\mathrm{pH}$ & 5.8 & 6.9 & \\
2. & COD & 112.3 & 76.4 & $\mathrm{mg} / \mathrm{L}$ \\
3. & Oils and Fats & 4.3 & 2.0 & $\mathrm{mg} / \mathrm{L}$ \\
4. & Ammonia & 11.2 & 7.8 & $\mathrm{mg} / \mathrm{L}$ \\
5. & Total Coliform & 3141 & 2167 & Total/100 mL \\
\hline
\end{tabular}

\section{BOD parameter of domestic waste}

The treatment was conducted with four repetitions for each HRT. The results of the treatment can be seen in the following Figure 1:

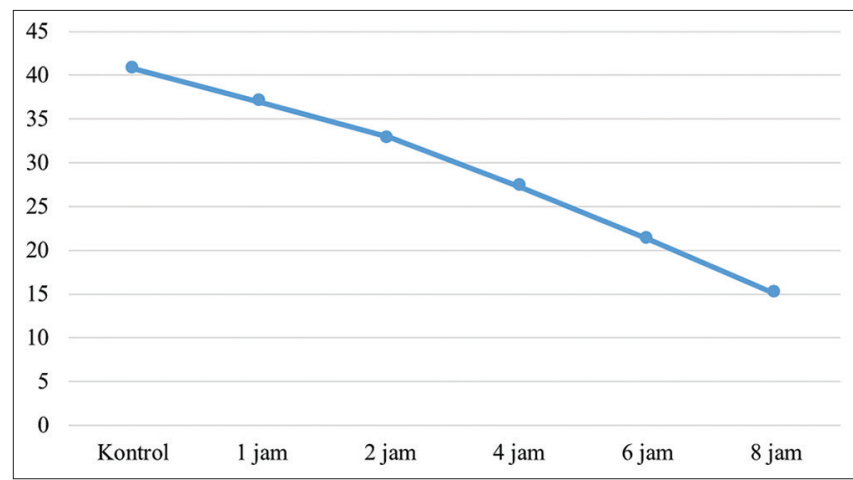

Figure 1: Graph of mean biochemical oxygen demand levels (mg/L) by hydraulic retention time

The percentage in BOD levels after treatment with various HRTs indicated a decrease of $2.4 \%$ in the control or without HRT, while the decrease in BOD in the HRT treatments of $1 \mathrm{~h}, 2 \mathrm{~h}, 4 \mathrm{~h}, 6 \mathrm{~h}$, and $8 \mathrm{~h}$ were $11.7 \%, 21.3 \%, 34.7 \%, 49.0 \%$, and $64.1 \%$, respectively.

\section{TSS parameter treatment}

The treatment was conducted with four repetitions for each HRT. The results of the TSS parameter treatment can be seen in the following Figure 2:

Based on the Figure 2, it can be seen that the highest decrease in BOD occurred at HR of $8 \mathrm{~h}$, namely,

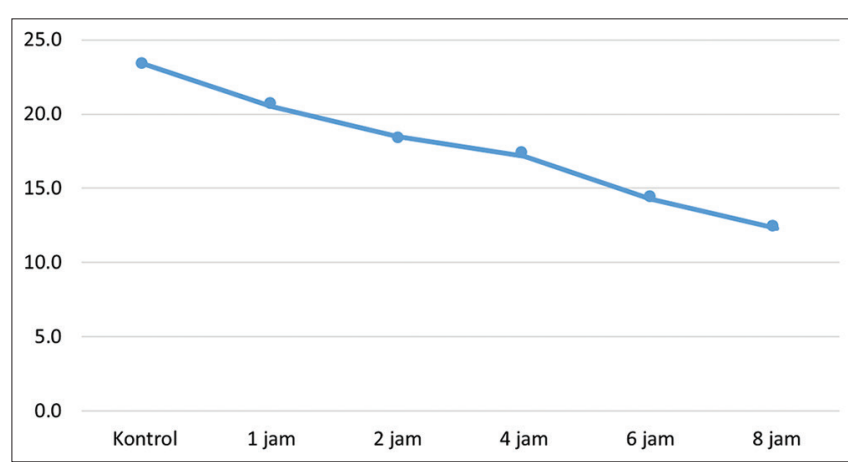

Figure 2: Graph of mean total suspended solid Levels ( $\mathrm{mg} / \mathrm{L})$ by hydraulic retention time

$12.3 \mathrm{mg} / \mathrm{l}$. After treatment with various HRTs, it was revealed that there was a decrease in TSS levels of the control or without HRT by $5.6 \%$, while the decreases in TSS levels for the treatment with HRTs of $1 \mathrm{~h}, 2 \mathrm{~h}, 4 \mathrm{~h}$, $6 \mathrm{~h}$, and $8 \mathrm{~h}$ were $17.3 \%, 25.4 \%, 30.6 \%, 42.3 \%$, and $50.4 \%$, respectively.

\section{Discussion}

Shells are composed of compounds such as calcium carbonate, chitin, calcium hydroxyapatite, and calcium phosphate. Most shells contain chitin which is a natural polysaccharide that has many uses, such as chelating agents, emulsifiers, and adsorbents [11] so that shells can be used as a filtration medium to raise the $\mathrm{pH}$ of wastewater. Shell also has a removal value of COD parameter up to 80.6 percent at media thickness of $122 \mathrm{~cm}$ and HRT of $36 \mathrm{~h}$ [12]. Aerobic biofilter is also effective in reducing $C O D$ in rubber industry waste with a seeding time of 1 week and can remove COD as much as $840 \mathrm{mg} / \mathrm{l}$ [13]. The effectiveness for the fatty oil parameter was supported by the fatty oil separation process using a grease trap on the waste carrier channel to the biofilter inlet.

Optimization of grease trap has been proven to be able to separate fatty oil in wastewater by utilizing a density of fatty oil that is lighter than water (oil: $0.8 \mathrm{~m}^{3} / \mathrm{g}$, fat: $0.8-0.9 \mathrm{~m}^{3} / \mathrm{g}$, and water: $1 \mathrm{~m}^{3} / \mathrm{g}$ ) [14]. The result of gray water domestic wastewater treatment is an alternative source to meet water needs for watering/ greening plants, in addition to reducing the volume and pollutant load of wastewater that flows into the city drainage system or surface/river water bodies. Wastewater treatment using anaerobic and aerobic biofilters or a combination of both is quite effective in reducing the levels of organic waste parameters such as BOD, COD, TSS, Ammonia, TDS, and Total Coliform with affordable operational costs [15]

The biofiltration process uses special media as a habitat for microorganisms such as bioball and kaldness by utilizing the basic nature of decomposing 
bacteria. These microorganisms have the character of breaking down dirt so as to produce clean water that is free of contaminants. Habitat built up through the filtration media will make decomposing bacteria grow and develop which is characterized by the appearance of a mucus-like layer or commonly known as a biofilm. Biofilm formed on walls planted with plants or filtration media can reduce turbidity, color, COD, total organic carbon, BOD, and E. coli concentration, and total coliforms [16].

BOD is one of the main characteristics of wastewater which indicates the amount of dissolved oxygen required by microorganisms to decompose organic matter under aerobic conditions. Organic matter decomposed in BOD is organic material that is ready to be decomposed. BOD can also be interpreted as the amount of oxygen used by microorganisms in the waters in response to the entry of organic matter that can be decomposed. High concentration of BOD in aquatic system mainly comes from anthropogenic sources, which consist of domestic and livestock waste, which can reduce oxygen availability, the number of aquatic habitats and biodiversity, as well as water quality [17].

The concentration of BOD in domestic waste treatment reactor can be reduced by up to $64 \%$ due to the intervention of HRT. HRT is the average residence time of wastewater in the aeration tank to get good results in the biological treatment process. The longer the wastewater in the aeration tank, the greater the decrease in BOD. The effect of media depth, HRT and dissolved oxygen on the removal of various pollutants in waste showed that increasing the media depth in the reactor would increase HRT and increased DO so as to improve water quality [18].

Not only HRT analysis, BOD analysis also took a long time. Biochemical oxidation is a slow process. Within 20 days, the oxidation of carbon organic matter reaches $95-99 \%$, and within 5 days about $60-70 \%$ of organic matter has been decomposed [19].

Besides HRT, the seeding and running processes had a major effect on the decrease in BOD. Optimally the running process can be carried out for up to 40 days [20]. The running process in the reactor used in this study was conducted with a minimum limit of 14 days. A previous study that integrated the concept of microbial electrochemical technology with biofilters used in artificial wetlands was able to optimally remove BOD concentrations of up to $99 \%$ at the highest HRT of 3.4 days or $81 \mathrm{~h}$ [21]. Another study showed that Anaerobic Baffled Reactor technology followed by a biofilter reactor with rock media was proven to be able to decrease the organic matter BOD with a removal rate of $78-99 \%$. The evaluation of such study showed that the concentration of BOD in the waste would decrease in line with HRT and operational time [22]. In addition, shells are also used as an alternative medium for anaerobic filters to decrease the levels of BOD in domestic waste. The highest decrease in the levels of BOD was 89.91 percent, which was obtained at media thickness of $122 \mathrm{~cm}$ and HRT of $36 \mathrm{~h}$ [12].

The presence of TSS can further reduce oxygen production because it interferes with the penetration of light required for photosynthesis by plants [23]. Sunlight absorbed by suspended particles may increase the temperature of the water which further reduces the oxygen holding capacity of warm water and disturbs cold water biota. The presence of aerobic decomposing bacteria in the reactor can reduce the amount of suspended solids in the water within a certain time.

A study conducted in the Keputih area, Surabaya treated restaurant wastewater with an unpleasant odor using an aerobic biofilter process with gravel and natural stone media. The HRTs applied were $6 \mathrm{~h}$ and $8 \mathrm{~h}$ with down-flow. The analyzed parameters were BOD, COD, and TSS. The results showed that the TSS removal efficiency of $95 \%$ occurred in an 8-h HRT aerobic biofilter reactor with gravel media [24].

The length of HRT in the aeration tank was proven to significantly increase the life expectancy of decomposing microorganisms by reducing the overall contaminant load delivered to the biofilter. Five days HRT and constant airflow rate of $3.4 \mathrm{~m}^{3} /$ day could remove $99 \%$ of Ammonia in the aeration tank after 3 weeks. Removal efficiencies above $80 \%, 90 \%$, and $86 \%$ were recorded for COD, CBOD5, and $\mathrm{NH} 3-\mathrm{N}$ after 6 weeks of operation [25].

A study on the combination of aerobic biofilter with honeycomb plastic media and gravel media was carried out to treat domestic wastewater. The combination at 24-h HRT was proven to decrease the levels of COD, NH4-N, TSS by $84.09 \%, 81.62 \%$, $93.9 \%$, respectively. At $36 \mathrm{~h}$ HRT, it decreased COD, NH4-N, TSS by $76.68 \%, 97.67 \%, 85.04 \%$, respectively. Efficiency was influenced by variations in HRT and treatment at 24-h HRT to improve reactor performance. $36 \mathrm{~h}$ HRT was chosen as the optimum HRT with even aeration [26]. Another study which aims to treat batik industrial wastewater which applied a biofilter integration of horizontal subsurface flow constructed wetlands revealed the reduction efficiency for the COD, TSS, and oil and fat parameters by $72.67-86.67 \%$; 95.85-98.18\%; and 79.47-90.04\%, respectively [27]. In addition, the biofilter using shellfish filtration media obtained the best removal results for the TSS parameter at a media thickness of $80 \mathrm{~cm}$ and a 24-h HRT by $91.76 \%$ [12].

HRT is a very important key parameter that can increase the removal rate of all pollutant substances in wastewater treatment in accordance with the target. The study results obtained for more than a year showed that HRT could produce stable performance within 15 days. Then the biofilter was able to maintain its good performance when HRT was reduced gradually until it became ineffective in 1.2 days [28]. 
In this study, the TSS reduction rate was still $50 \%$ at the maximum HRT tested of $8 \mathrm{~h}$. This could be due to HRT and the short feeding and running time. The increase in HRT, feeding, and running time is expected to increase the removal rate, especially for TSS parameter as shown in several previous studies.

The results of statistical analysis showed that four different types of tests obtained a significant $P$ value of 0.000 . This finding indicated that there was a significant effect of HRT on the levels of BOD and TSS of domestic waste with a $p<0.05$ at the $95 \%$ confidence level. Based on the results of the Bonferroni test, it can be concluded that there were differences in BOD levels by HRT between the control and all HRTs applied in the experiment, namely $1 \mathrm{~h}, 2 \mathrm{~h}, 4 \mathrm{~h}, 6 \mathrm{~h}$ and $8 \mathrm{~h}$. Furthermore, there were also differences in TSS levels by HRT between the control and all HRTs applied in the experiment, namely $1 \mathrm{~h}, 2 \mathrm{~h}, 4 \mathrm{~h}, 6 \mathrm{~h}$ and $8 \mathrm{~h}$.

\section{Conclusion}

There was a significant correlation between HRT of $1 \mathrm{~h}, 2 \mathrm{~h}, 4 \mathrm{~h}, 6 \mathrm{~h}$, and $8 \mathrm{~h}$ and the BOD and TSS parameters of Domestic Wastewater. The quality of Domestic Wastewater after simple integrated treatment has met the quality standards established in the Regulation of the Minister of Environment and Forestry of the Republic of Indonesia Number: P.68/ Menlhk/Setjen/2016.

\section{References}

1. Supriyatno B. Environmentally sound waste water management is a strategy and steps to deal with it. J Teknol Lingkung. 2000;1(1):159. https://doi.org/10.29122/jtl.v1i1.159

2. Susanti R. Mapping of Clean Water Supply System Issues to Improve the Quality of Clean Water Supply System in Sawahlunto City. J Reg City Plan. 2010;21(2):111-28.

3. Andiese VW. Treatment of household liquid waste using the oxidation pond method. J Tek Sipil Infrastruktur. 2010;1(2):103-10.

4. Indonesia R. Permen Lingkungan Hidup dan Kehutanan Republik Indonesia nomor tahun 2016 Tentang Baku Mutu Air Limbah Domestik. Jakarta: Sekretariat Negara; 2016. p. 68.

5. Arief LM. Pengolahan Limbah Industri: Dasar-Dasar Pengetahuan dan Aplikasi di Tempat Kerja. Penerbit Andi; 2016.

6. Siregar SA. Instalasi Pengolahan air Limbah. Kanisius; 2005.

7. Falahati H, Karimi Jashni A, Rakhshandehroo G. Effects of hydraulic retention time on the performance of a membrane bioreactor treating municipal wastewater. Water Wastewater. 2017;28(4):93-102. https://doi.org/10.22093/wwj.2017.45876

8. Pribadi RN, Zaman B, Purwono P. Effect of Kiambang (Salvinia Molesta) Closure Area on eduction of COD,Ammonia, Nitrite, and Nitrate in Domestic Liquid Waste (Grey Water) with
Continuous System. J Tek Lingkung. 2016;5(4):1-10.

9. Tim Sanitasi Kota Banda Aceh. Strategi Sanitasi Kota. Vol. 1. Tim Sanitasi Kota Banda Aceh; 2009.

10. Pohan N. Pengolahan Limbah Cair Industri tahu Dengan Proses Biofilter Aerobik; 2008.

11. Khiri MZ, Matori KA, Zaid MH, Abdullah AC, Zainuddin N, Jusoh WN, et al. Soda lime silicate glass and clam shell act as precursor in synthesize calcium fluoroaluminosilicate glass to fabricate glass ionomer cement with different ageing time. J Mater Res Technol. 2020;9(3):6125-34. https://doi.org/10.1016/j.jmrt.2020.04.015

12. Rokhmadhoni RA. Kulit Kerang Sebagai Media Alternatif Filter Anaerobik Untuk Mengolah Air Limbah Domestik. Institut Teknologi Sepuluh; 2019.

13. Nurjanah S, Zaman B, Syakur A. Removal of Bod and Cod of Rubber Industry Liquid Waste with Aerobic Biofilter System and Plasma Dielectric Barrier Disshare (Dbd). J Tek Lingkung. 2017;6(1):1-14

14. Yudo S, Said NI. Status of Ciliwung River Water Quality in DKI Jakarta Area Case Study: Installation of Online Water Quality Monitoring Station in Kelapa Dua Segment - Istiqlal Mosque. J Teknol Lingkung. 2018;19(1):13-22. https://doi.org/10.29122/ jtl.v19i1.2243

15. Busyairi M, Adriyanti N, Kahar A, Nurcahya D, Sariyadi S. The Effectiveness of Gray Water Domestic Wastewater Treatment With Anaerobic Biofilter and Aerobic Biofilter Process (Case Study: INBIS IPAL Permata Bunda, Bontang). J Serambi Eng. 2020;5(4):1306-12.

16. Bakheet B, Prodanovic V, Deletic A, McCarthy D. Effective treatment of greywater via green wall biofiltration and electrochemical disinfection. Water Res. 2020;185:116228. https://doi.org/10.1016/j.watres.2020.116228 PMid:32736285

17. VigiakO, GrizzettiB, Udias-MoineloA,ZanniM,DoratiC,BouraouiF, et al. Predicting biochemical oxygen demand in European freshwater bodies. Sci Total Environ. 2019;666:1089-105. https:// doi.org/10.1016/j.scitotenv.2019.02.252 PMid:30970475

18. Abou-Elela SI, Hellal MS, Aly OH, Abo-Elenin SA. Decentralized wastewater treatment using passively aerated biological filter. Environ Technol. 2019;40(2):250-60. https://doi.org/10.1080/09 593330.2017.1385648 PMid:29025371

19. Beutler M, Wiltshire $\mathrm{KH}$, Meyer B, Moldaenke C, Luring C Meyerhofer M, et al. A fluorometric method for the differentiation of algal populations in vivo and in situ. Photosynth Res 2002;72:39-53.

20. Putri AR. Determination of the optimal BOD/COD ratio in aerobic, facultative and anaerobic reactors. J Tek Lingkung. 2013;2(1):1-5.

21. Aguirre-Sierra A, Bacchetti-De Gregoris T, Berná A, Salas JJ, Aragón C, Esteve-Núñez A. Microbial electrochemical systems outperform fixed-bed biofilters in cleaning up urban wastewater. Environ Sci Water Res Technol. 2016;2(6):984-93.

22. Hendriarianti E, Karnaningroem N. Evaluation of communa wastewater treatment plant operating anaerobic baffled reactor and biofilter. Waste Technol. 2016;4(1):7-12. https://doi. org/10.14710/4.1.7-12

23. Shah S, Yusof KW, Mustaffa Z, Mustafa A. Concentration of total suspended solids (TSS) influenced by the simulated rainfal event on highway embankment. IACSIT Int J Eng Technol. 2014;6(6):493-6. https://doi.org/10.7763/IJET.2014.V6.747

24. Zahra LZ. Pengolahan Limbah Rumah Makan dengan Proses Biofilter Aerobik. Institut Teknologi Sepuluh Nopember; 2015.

25. Champagne P, Khalekuzzaman M. A semi-passive peat biofilter system for the treatment of landfill leachate. J Water Sustain. 2014;4(2):63. https://doi.org/10.11912/jws.4.2.63-76 
26. Azmi KN, Danumihardja IG, Said NI. Application Of Domestic Wastewater Treatment Technology Using A Combination Of Aerobic Biofilter Plastic Wasps And Gravel Media Biofilter With Upper Flow. J Air Indones. 2018;10(2):3760. https://doi. org/10.29122/jai.v10i2.3760

27. Rahmadyanti E, Wiyono A, Firmansyah GA. Integrated system of biofilter and constructed wetland for sustainable batik industry. Int J. 2020;18(70):138-48.

28. Chen YF, Ng WJ, Yap MG. Performance of upflow anaerobic biofilter process in pharmaceutical wastewater treatment Resour Conserv Recycl 1994;11:83-91. https://doi. org/10.1016/0921-3449(94)90080-9 